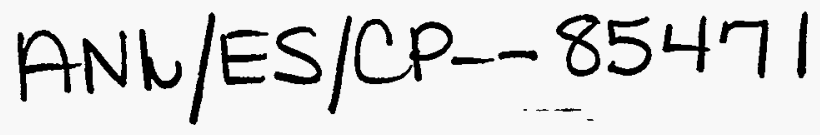

Corf $-950450--9$

\title{
SALINITY AND HYDRODYNAMICS OF THE HOLOCENE AND UPPER PLEISTOCENE BENEATH THE LOUISIANA WETLANDS FROM ELECTRICAL MEASUREMENTS*
}

\author{
L.D. McGinnis, M.D. Thompson, G.J. Kuecher, and P.L. Wilkey \\ Argonne National Laboratory \\ Argonne, Ill. 60439 \\ and \\ H.R. Isaacson \\ Gas. Research Institute \\ Chicago, IIl. 60631-3562
}

\section{DISCLAIMER}

\begin{abstract}
This report was prepared as an account of work sponsored by an agency of the United States Government. Neither the United States Government nor any agency thereof, nor any of their employees, makes any warranty, express or implied, or assumes any legal liability or responsiprocess disclicuracy, completeness, or usefulness of any information, apparatus, product, or process disclosed, or represents that its use would not infringe privately owned rights. Refermanufacturer, or otherwise hemmercial product, process, or service by trade name, trademark, mendation, or faver necessarily constitute or imply its endorsement, recommendation, or favoring by the United States Government or any agency thereof. The views United States Government or any agerein do not necessarily state or reflect those of the
\end{abstract}

The submitted manuscript has been authored by a contractor of the $U . S$. Government under contract No. W-31-109-ENG-38.

Accordingly, the U.S. Government retains a nonexclusive, royalty-free license to publish or reproduce the published form of this contribution, or allow others to do so, for U. S. Government purposes. \section{DISTABUTION OF THIS DOCUMEN :}

- This work was supported by the Gas Research Institute, Chicago, Illinois, through contract 5088-252-1770 with the Department of Energy. 


\section{DISCLAIMER}

Portions of this document may be illegible in electronic image products. Images are produced from the best available original document. 


\title{
SALINITY AND HYDRODYNAMICS OF THE HOLOCENE AND UPPER PLEISTOCENE BENEATH THE LOUISIANA WETLANDS FROM ELECTRICAL MEASUREMENTS*
}

\author{
L.D. McGinnis, M.D. Thompson, G.J. Kuecher, and P.L. Wilkey \\ Argonne National Laboratory \\ Argonne, IIl. 60439 \\ and \\ H.R. Isaacson \\ Gas Research Institute \\ Chicago, III. $60631-3562$
}

\begin{abstract}
A conceptual hydrodynamic model in the Holocene and upper Pleistocene beneath the Louisiana wetlands is described in terms of salinity distributions. Porewater salinity is calculated from electrical measurements, including resistivity soundings, electric logs, and electromagnetic profiling. Electrical measurements support the primary, basin-wide groundwater flow model; however, the data also indicate secondary contributions from expulsion of fluids under geopressure along active growth faults and from original waters of deposition. Expulsion of water from growth faults has been described previously for deeper sections of the Pleistocene, but has not been reported for the Holocene or upper Pleistocene beneath the Louisiana wetlands. Porewater chemistry variations beneath the coastal wetlands are a consequence of the following (in order of importance): (1) environment of deposition; (2) a basin-wide, regional flow system; (3) expulsion from deep-seated growth faults; and (4) pore water extrusion due to compaction. Water chemistry in Holocene clays and muds is influenced primarily by the deposition environment. In Pleistocene sands, the chemistry is a function of the other three factors.
\end{abstract}

\section{INTRODUCTION}

Electrical measurements have been obtained to determine the porewater salinity of the Holocene and upper Pleistocene strata that underlie the Louisiana wetlands (Figure 1). These studies were conducted to provide insight into the causes of wetland loss; however, salinity distribution data are also applicable to growth fault mapping and hydrodynamics, studies of coastal zone groundwater geology, environments of deposition, global climate change, coastal emergence and submergence, and generation and evolution of hydrocarbon source beds and geopressured zones (McGinnis et al., 1992a, 1992b).

Surficial processes in the delta complex have entered a destructive delta cycle in response to rapid subsidence relative to sea level (Penland et al., 1988). Marine processes are replacing deltaic processes as wetlands are converted to open continental shelf.

Although electrical measurements were obtained primarily in the Mississippi delta plain, it is likely that the general chemical and physical characteristics of the Holocene and Pleistocene are similar across the entire northern Gulf Coast.

\section{GEOLOGY AND HYDROGEOLOGY}

The delta plains of the Mississippi drainage system are underlain by clay-rich, organic sediments referred to as the Topstratum; these sediments, of Holocene age, rest on the more permeable sands of the lower Holocene and upper Pleistocene units of the Substratum (Fisk, 1944). The physical boundary separating these facies is a prominent unconformity that also represents a fundamental hydrogeological and hydrogeochemical discontinuity. Bernard and LeBlanc (1965) describe the Pleistocene sediments at the discontinuity as "stiff and mottled, oxidized, and/or leached. Lime nodules, caliche, and ferruginous concretions frequently occur in the Pleistocene. The overlying Holocene sediments have a relatively greater moisture content, are soft; consist of silt, sand and clay; and contain abundant organic remains."

\footnotetext{
* This work was supported by the Gas Research Institute, Chicago, Illinois, through contract 5088-252-1770 with
} the Department of Energy. 


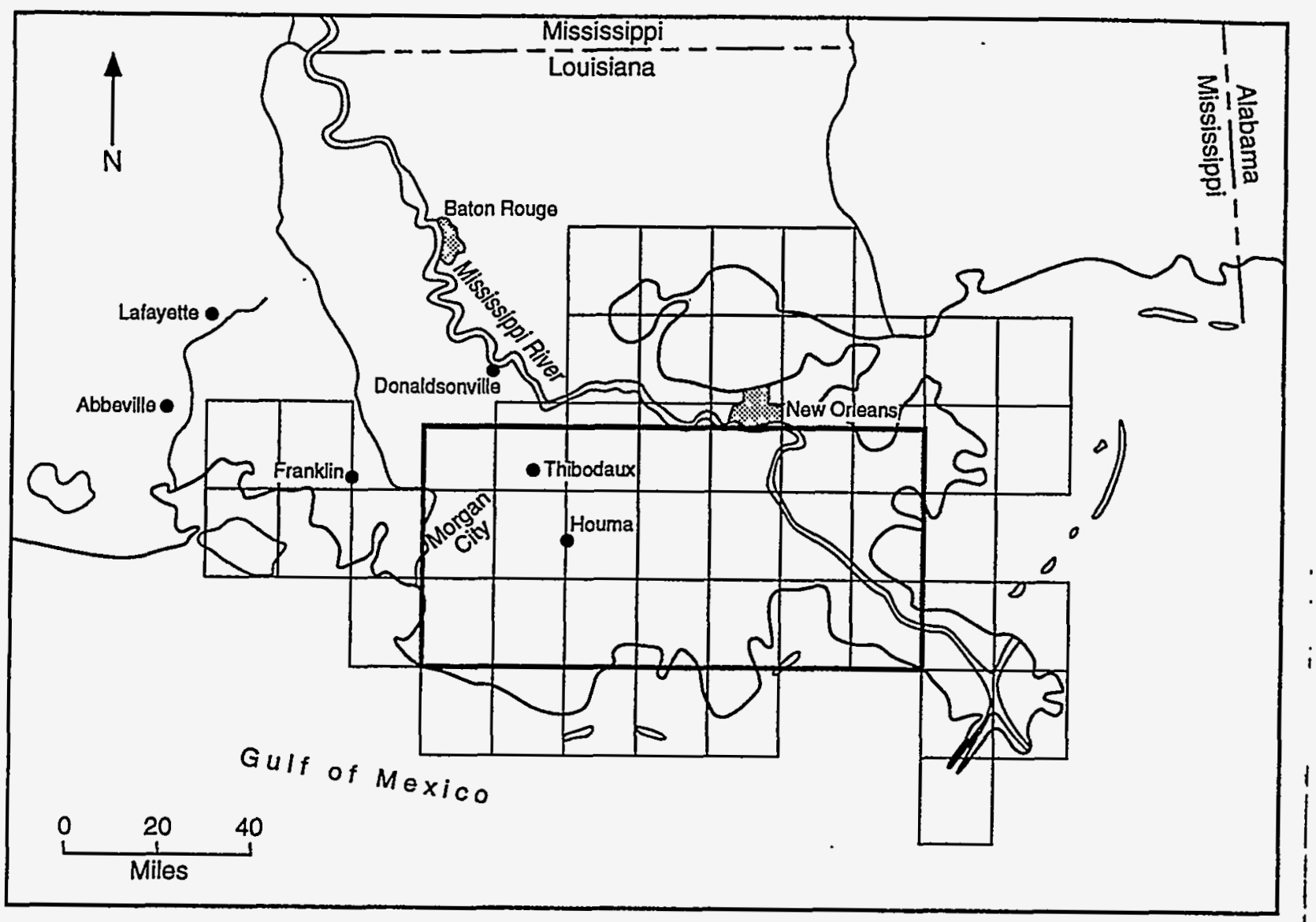

FIGURE 1 Location map of study area in the Louisiana wetland

The Topstratum, ranging up to $100 \mathrm{~m}$ thick near the coast, was deposited following the last major retreat of North American ice sheets (Kuecher, 1994). The Substratum consists of fluvial sands that were deposited during the last low sea level stand at the end of the Pleistocene Epoch.

\section{Surface Water}

Where groundwater is hydraulically connected with the sea, the Ghyben-Herzberg equation can be used to define the slope of the interface between salt water and freshwater (Dominico, 1972). The interface slopes landward at an angle dependent on the seaward slope of the water table and the densities of the two fluids, according to Equation 1.

$$
\mathrm{Z}=\mathrm{P}_{\mathrm{f}} * \mathrm{H}_{\mathrm{f}} /\left(\mathrm{P}_{\mathrm{s}}-\mathrm{P}_{\mathrm{f}}\right)
$$

where $\mathrm{Z}$ is the depth below sea level to the freshwater/saltwater contact, $\mathrm{H}_{\mathrm{f}}$ is the freshwater hydraulic head above sea level (height of water table), and $\mathrm{P}_{\mathrm{f}} /\left(\mathrm{P}_{\mathrm{s}}-\mathrm{P}_{\mathrm{f}}\right)$ is the ratio of the density of freshwater to the difference in density between salt and freshwater.

For static sea level, Dominico (1972) provides the following equation for the angle of interface:

$$
\sin \mathrm{a}=\mathrm{P}_{\mathrm{f}} /\left(\mathrm{P}_{\mathrm{s}}-\mathrm{P}_{\mathrm{f}}\right) * \mathrm{q} / \mathrm{K}
$$

where $\mathrm{q}$ is the specific discharge and $\mathrm{K}$ is a proportionality constant.

Figure 2 illustrates the theoretical shape of the interface for coastal Louisiana. Depths to high-salinity porewater, based on electrical depth soundings, are also plotted on Figure 2. 


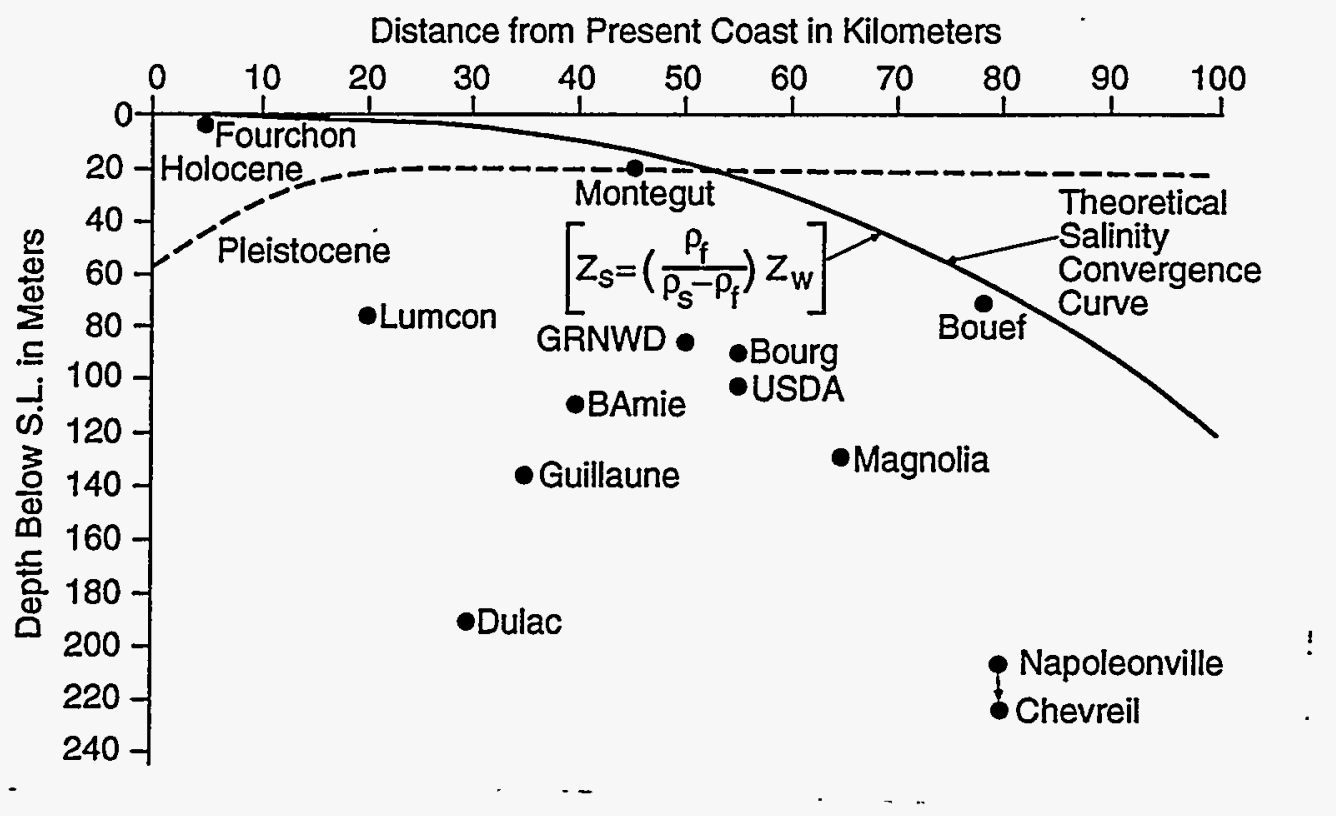

FIGURE 2 Theoretical freshwater/saltwater boundary in the wetlands from the GhybenHerzberg equation

Groundwater

The coastal zones of Louisiana are recognized as part of a regional hydrogeologic system (Grubb, 1986). Tertiary through Quaternary sediments were deposited in cyclical, transgressive-regressive sedimentary sequences. Sedimentation in these sequences occurred at the end of deposition of the Vicksburg and Jackson Groups. These groups represent a geopressured zone considered to be a confining unit at the base of the Coastal Lowlands Aquifer System (Martin and Whiteman, 1989) that consists of a major transgressive sequence that immediately preceded the onset of southern hemisphere glaciation in the late Oligocene. Abnormally high fluid pressures are maintained in the basal geopressured zone - movement of fluids through this zone is minor compared with fluid movement in the overlying sediments, where pressure is more normal (Grubb, 1986). The Topstratum is believed to be the uppermost confining layer, although flow tests have not been conducted on this formation. Figure 3 shows a generalized, north-south, hydrogeologic cross section in eastern Louisiana, modified from Martin and Whiteman (1989). Groundwater flow is directed upward and toward the coast.

Electrical measurements can be interpreted according to the basin-wide hydrogeologic model described by Martin and Whiteman; however, a more complex system must be defined in order to account for the anomalous salinities observed in both the Topstratum and Substratum. The system includes waters of deposition in the Holocene clays and high-salinity waters discharging from growth faults as described by Anderson et al. (1994). Anderson et al. (1994) describe active seeps at the sea floor along the large growth fault system near Eugene Island. Oil and gas are being produced beneath these seeps in reservoirs as young as 400,000 years old. On the basis of these observations, growth faults similarly affect the hydrogeochemical system observed in the Louisiana wetlands.

\section{ELECTRICAL MEASUREMENTS AND SALINITY}

Formation resistivities (in ohm-meters [ohm-m]), determined from inversion of electrical depth sounding curves, are converted to porewater resistivity and salinity. The formation resistivities interpreted from electrical depth soundings are referred to in later discussions as "bulk" resistivities to indicate the smoothing effect that occurs during surface measurements. 


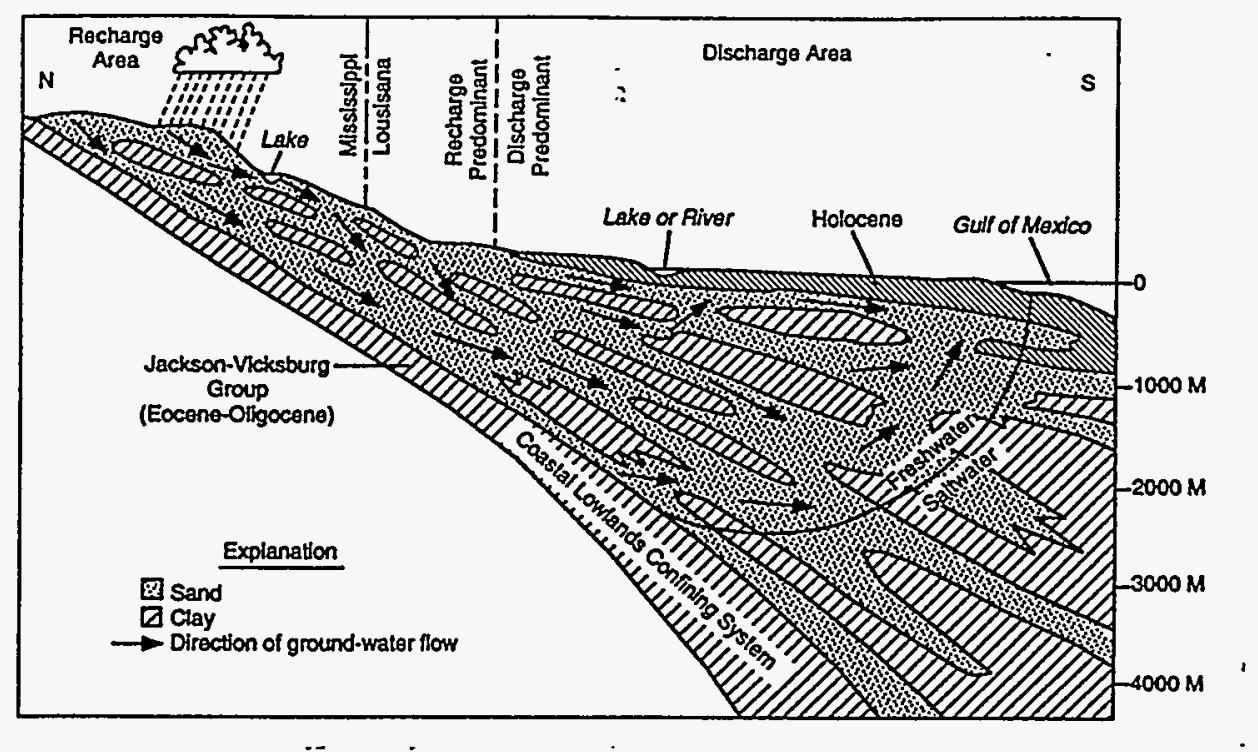

FIGURE 3 Conceptual model of basin-wide groundwater flow in the Coastal Lowland Aquifer System (from Martin and Whiteman, 1989)

If bulk resistivity and an initial salinity are known, a formation factor can be derived. The dimensionless formation factor $\left(F_{f}\right)$ is derived from the following equation:

$$
\mathrm{F}_{\mathrm{f}}=\mathrm{R}_{\mathrm{o}} / \mathrm{R}_{\mathrm{w}}
$$

where $R_{0}$ is the formation (bulk) resistivity and $R_{w}$ is the pore water resistivity.

The $\mathrm{F}_{\mathrm{f}}$ was determined for the Topstratum at several stations near the coast where sea water salinities of 35 parts per thousand (ppt) were measured. From these measurements, a $F_{f}$ of 1.42 was determined for the Topstratum. Turcan (1966) reports that the $F_{f}$ ranges from 2.4 to 4.0 for some of the principal aquifers in Louisiana; a value of 4.0 is reported for the Pleistocene. The low formation value found for the Topstratum is the result of extremely high porosities, ranging up to $90 \%$ for near-surface organic marsh sediments. As porewater and organics increase, the $\mathrm{F}_{\mathrm{f}}$ decreases and bulk resistivity and porewater resistivity values converge.

To convert electrical properties of the porewater to total dissolved solids, the resistivity is first converted to conductivity. Conductivity $(\mathrm{C})$ in millisiemens/meter $(\mathrm{mS} / \mathrm{m})$ is given by the following equation:

$$
\mathrm{C}=1,000 / \mathrm{R}_{\mathrm{w}} .
$$

Turcan (1966) found the following relationship between total dissolved solids and conductivity (C) for pore water in all major aquifers in Louisiana:

$$
\text { (C) })^{0.93}=\text { dissolved solids in } \mathrm{ppm} \text {. }
$$

The mean value of the exponent for the Holocene in the present study was found to be 0.975 . From the above equations, salinity $(\mathbf{S})$ in parts per thousand can be derived by using the following equation:

$$
S_{p p t}=\left(F_{f} / R_{f} \times 10^{4}\right)^{0.975} \times 10^{-3} .
$$

Turcan states that groundwater with a chloride content of $250 \mathrm{ppm}$ or less is considered fresh in Louisiana. Powell (1966) defines the relationship between salinity and chlorinity by the equation:

Chlorinity $=\left(S_{\mathrm{ppt}}-0.03\right) / 1.805$. 
On the basis of this relationship and regional measurements of bulk resistivity for the Topstratum and Substratum over the delta plain, the mean chlorinity of the porewater in Holocene sediments of coastal Louisiana is an order of magnitude greater than that considered fresh by Turcan.

\section{ELECTRIC LOGS AND SOUNDINGS}

Core and geophysical logs were obtained from two boreholes drilled through the Topstratum in southeastern Terrebonne Parish (Roberts et al., 1991). The electric log recorded at the Louisiana Universities Marine Consortium (LUMCON) in Cocodrie, Louisiana, is shown in Figure 4. Cyclic depositional patterns are observed in the core (Kuecher et al., 1993); these patterns include a wide range of sedimentary environments, from brackish/marine bay sediments to natural levees of major channels. The long-normal ILD Schlumberger electric log from the borehole at LUMCON was digitized at 1 -m intervals and compared with a Schlumberger electrical depth sounding. Resistivities increase from approximately $0.5 \mathrm{ohm}-\mathrm{m}$ near the surface to just under $8 \mathrm{ohm}-\mathrm{m}$ near the bottom of the hole.

The electrical depth sounding was taken along an access road located $150 \mathrm{~m}$ east of the borehole. Absolute values of the resistivities interpreted from the sounding curves are the same order of magnitude as those observed on the log; however, as expected from electrical depth sounding theory, the detail shown on the logs is far greater than what could be interpreted from surficial measurements. The depth of exploration for the electrical sounding extends below the maximum drilling depth and indicates that deeper Substratum resistivities again decrease to values similar to those obtained for the Topstratum.

\section{REGIONAL SALINITIES}

Table 1 lists the resistivities calculated from inversion of a regional network of 42 Schlumberger electrical depth soundings. Stations were located from the modern Mississippi delta on the east to the Atchafalaya basin on the west (see Figures 5 through 8). Current electrode separations were increased from 4 to $600 \mathrm{~m}$, resulting in investigation depths of up to $200 \mathrm{~m}$. Resistivities for each of the formations were converted to salinities, and salinity data were contoured using a 5-km grid spacing. Mean formation salinities are $4.04 \mathrm{ppt}$ for the top of the Topstratum (TTS), $6.40 \mathrm{ppt}$ for the Topstratum (TS), $3.20 \mathrm{ppt}$ for the top of the Substratum (TSS), and $8.83 \mathrm{ppt}$ for the Substratum (SS).

The salinity map of the TTS (Figure 5) illustrates the distribution of salinities in the first undisturbed geologic unit below present cultural effects. The position of the 5-ppt contour line closely approximates the present boundary between salt and brackish marsh (based on vegetation). Contour control is poor on the west and south, near the coast, because of a lack of data points. Salinities found in the north and central portions of the study area are below $1 \mathrm{ppt}$ and increase to $12 \mathrm{ppt}$ in the south, near the coast.

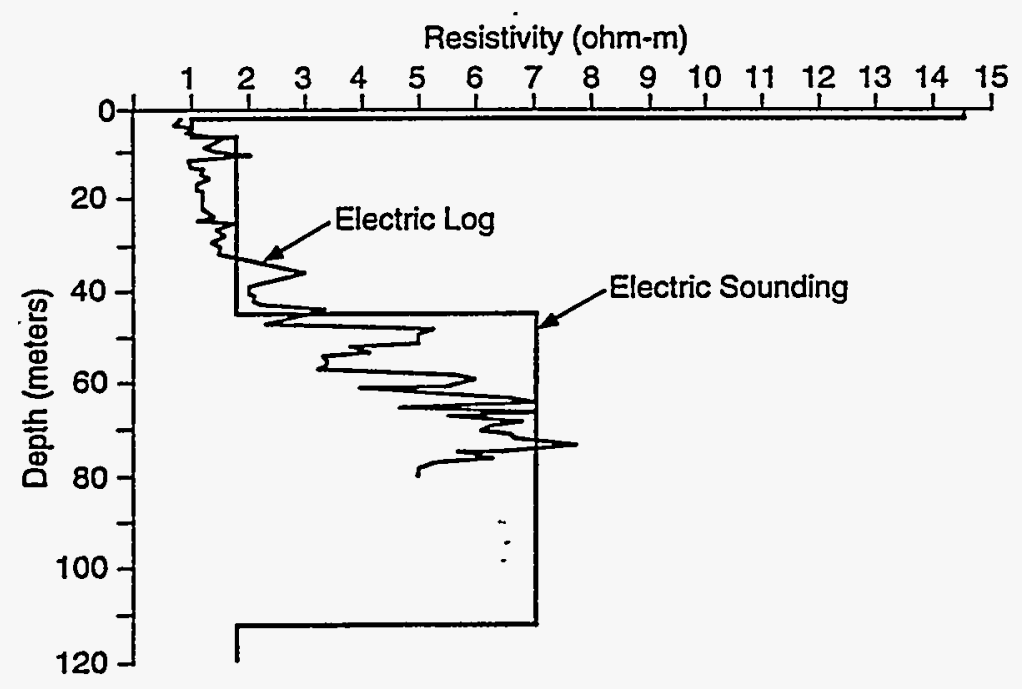

FIGURE 4 Electric log and electrical depth sounding at LUMCON in Cocodrie, Louisiana 
TABLE 1 Resistivities Calculated from Electrical Depth Soundings

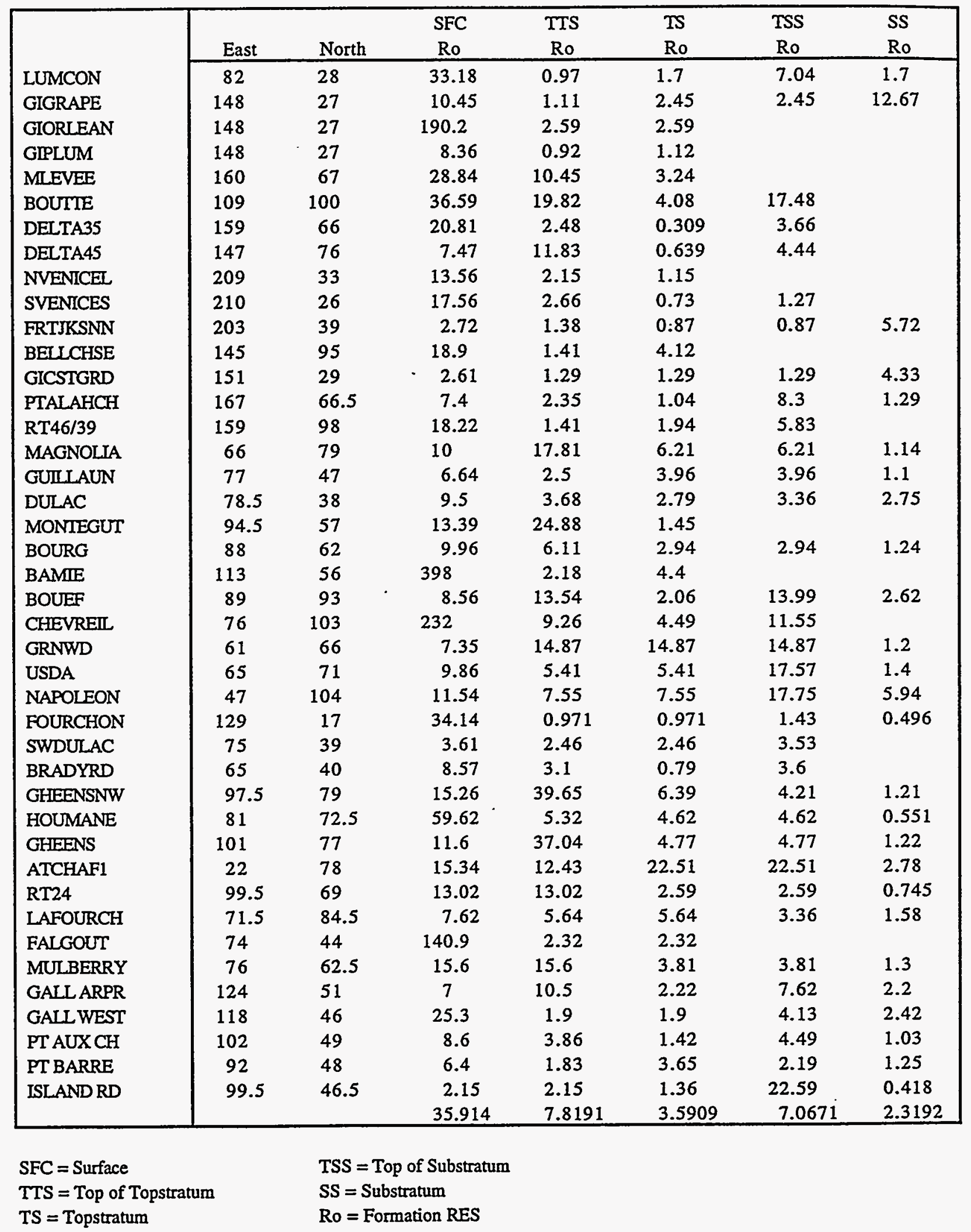




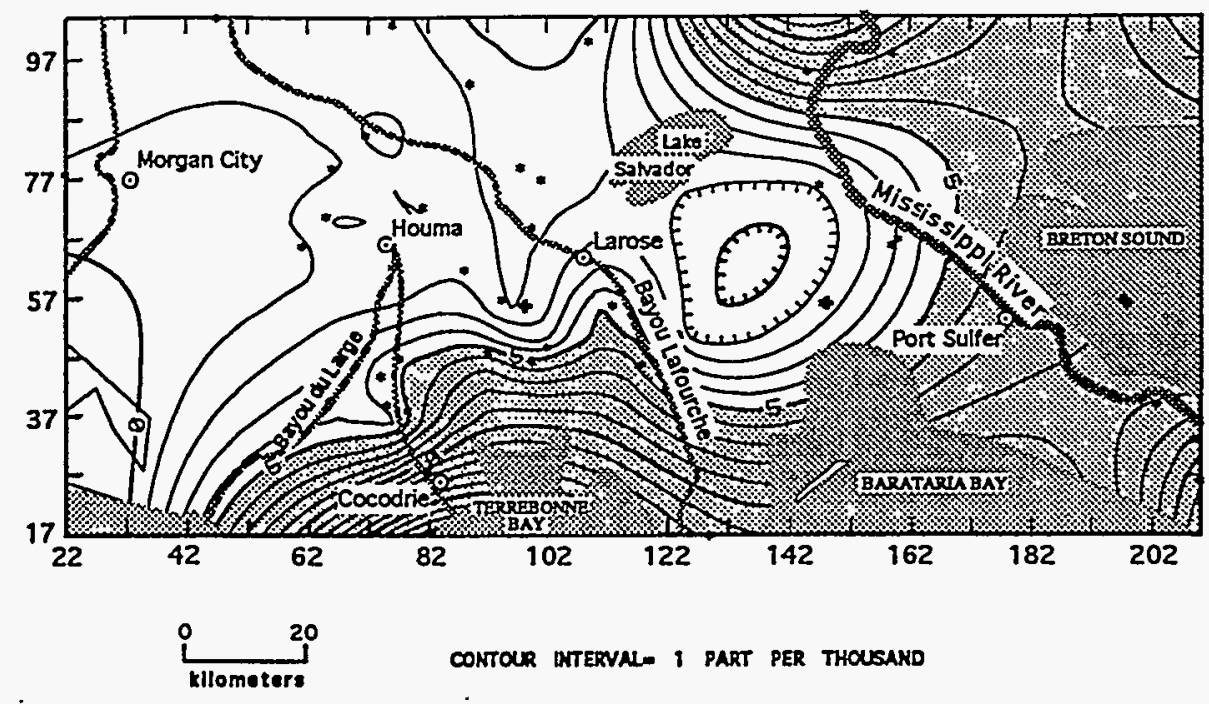

FIGURE 5 Top of Topstratum salinity map

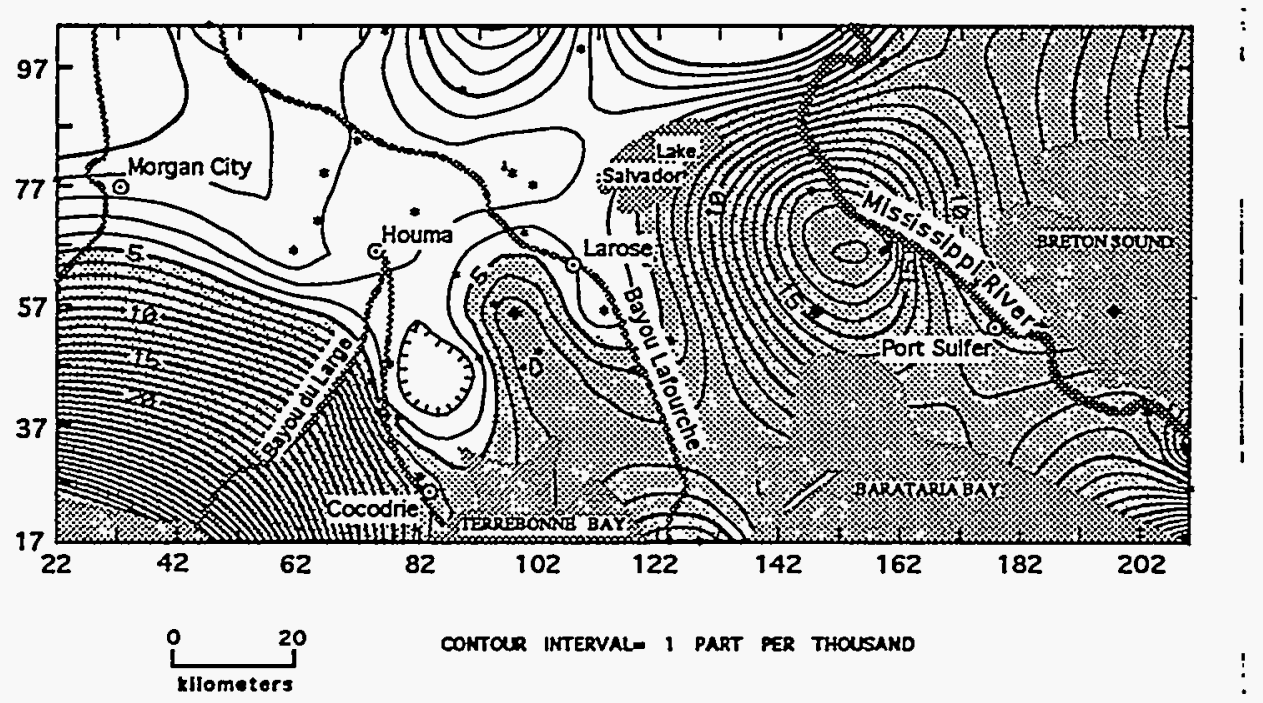

FIGURE 6 Topstratum salinity map

The salinity map of the TS (Figure 6) reflects conditions preserved in the geologic record and subsurface hydrodynamics. The buried facies are likely as diverse as the present wetlands, with former marshes reflecting their fresh, brackish, or salt characteristics in salinities ranging from $0.54 \mathrm{ppt}$ in the Atchafayala basin to the west to relatively high salinities of $18 \mathrm{ppt}$ or more near the coast. Broad, high-salinity lobes extend northward from Timbalier and Terrebonne Bay. Because of the large distance between stations, a quantitative estimate of horizontal salinity gradients cannot be made. The 5-ppt contour line occurs farther north in the TS than in either the TTS or present-day wetlands.

Salinities of the TSS (Figure 7) range from 0.5 to $8.9 \mathrm{ppt}$ Generally, salinities greater than $5 \mathrm{ppt}$ are observed in the far southeast corner of the map. A broad, elliptical zone of moderately high salinities is centered at map coordinates $92 \mathrm{E}, 57 \mathrm{~N}$. An extension of this zone extends to the northwest beneath Bayou Lafourche, paralleling a Pleistocene channel mapped by Kolb and Van Lopik (1958).

High salinities in the Substratum (Figure 8) extend farther north than in any of the overlying formations. A prominent, but discontinuous, high-salinity lobe extends to the northwest beneath Bayou Lafourche. High salinities in the lobe are associated with a Late Pleistocene paleochannel that contains a thick section of Substratum sands (Kolb and Van Lopik, 1958). The high salinity lobe extends north from modern bays, which include Terrebonne Bay on the west and Timbalier Bay on the east. 

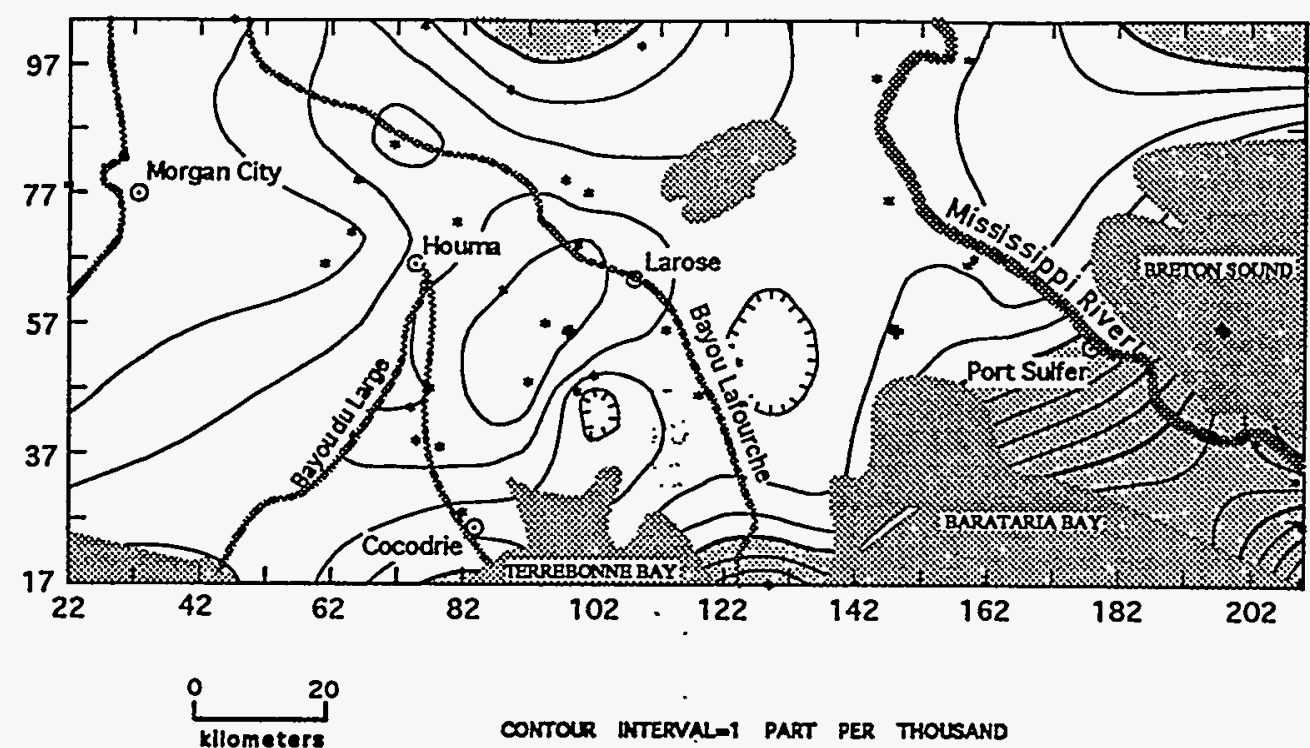

CONTOR ATERVAL-T PART PER THOLSAND

FIGURE 7 Top of Substratum salinity map

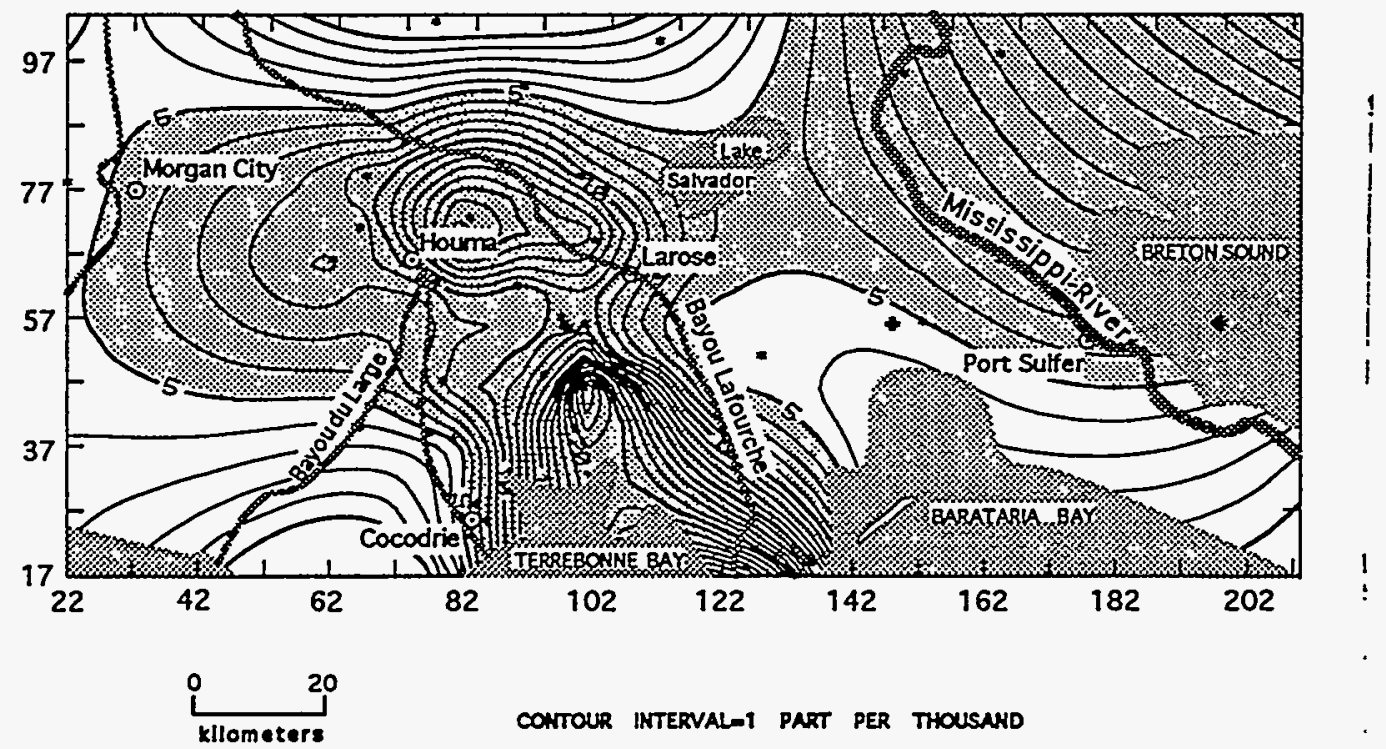

FIGURE 8 Substratum salinity map

If pore waters of the high transmissivity, Substratum sands contain abnormally high salinities, the salts must have been introduced following sand deposition. The Substratum was deposited during a period of low sea level, and original porewaters were fresh; therefore, a contemporary source for the high salinities must be identified. The discontinuous nature of the high salinity lobe in the Substratum suggests marine incursion is not the cause, or there would be a more gradual decrease of salinities northward. Rather, an internal cause of discontinuous salinities along the lobe is suggested.

Kuecher (1994) noted a general spatial coincidence of high salinity gradients and the surface projection of growth faults. A more rigorous relationship between the two could not be inferred because resistivity stations are located too far apart to constrain the location or magnitude of the gradients. For this reason, a decision was made to obtain electrical data of a more continuous nature across several faults. The electrical change across known faults was measured using a more rapid technique that provides better access to smaller areas. 


\section{ELECTROMAGNETIC PROFILING}

Following the resistivity study, three electromagnetic profiles were obtained using an EM-34 conductivity meter. The transects parallel the Bayou Du Large, Bayou Grand Caillou, and the Mississippi River in Baton Rouge. The Bayou Du Large transect, illustrated in Figure 9, was run across the Lake Hatch and the Golden Meadow fault zones. Station spacings averaged 0.5 mile. Conductivity measurements were made at coil spacings of 10,20 , and $40 \mathrm{~m}$ at each station in the vertical dipole mode, providing weighted mean conductivities to depths of 15,30 , and $60 \mathrm{~m}$, respectively. Prominent conductivity spikes are observed over two branches of the Lake Hatch Fault Zone on the Bayou du Large profile. A strong signal (above noise) is not apparent over the Golden Meadow Fault Zone. High-conductivity spikes over the Lake Hatch Fault Zone strongly suggest a causeand-effect relationship similar to that described by Roberts and Nunn (1994) for episodic geopressuring along growth faults.

\section{DISCUSSION}

The wetlands of coastal Louisiana are supported by a layered sequence of soft, impermeable sediments consisting of a complex organic, physical, and chemical confining unit that extends to the base of the Holocene. The sequence, referred to by Fisk (1944) as the Topstratum, ranges in thickness from several meters to $100 \mathrm{~m}$ or more near the coast. The base of the Topstratum is represented by a seismic discontinuity (Thompson et al., 1993) and lithologic unconformity (Bernard and Leblanc, 1965) and is underlain by a fluvial, Pleistocene-age sand designated by Fisk as the Substratum. The Topstratum and Substratum were deposited in complex interactions between coastal zone transgressive-regressive sequences, coastal zone hydrodynamics, growth faulting, and Pleistocene valley cutting.

Bulk resistivities and conductivities were used in this study to define the hydrogeochemistry of the Topstratum and Substratum. Electrical data indicate that salinities representative of salt marsh in most of the Holocene are found farther landward than present. Salinities representative of a salt marsh in the late Pleistocene and earliest Holocene are found farther seaward than present. In the conceptual drawing of the Coastal Lowland Aquifer System shown in Figure 3, only the sands are continually flushed by waters recharged in outcrop areas to the north. Confining clays of the Holocene remain hydrodynamically and hydrogeochemically isolated from the regional flow system.

Electrical soundings indicate that the regional scenario defines the system quite well, but with a major refinement. Water chemistry in the Substratum is recharged not only by the regional freshwater flow system, but also by waters episodically triggered by growth fault movement and by waters of compaction. The intersection of suborthogonal paleochannels and growth faults results in the invasion of saline groundwater from deep geopressured aquifers (Hunt, 1990) into shallow, fluvial sands of the Substratum. This condition is predicted in numerical models described by Roberts and Nunn (1994). Where growth faults cut less permeable units, such as interlobate clays and organic paleo- marsh units, the broad, higher-salinity signature is not observed. The penetration distance of geopressured groundwater varies depending on hydraulic conductivity along the face of the faults. The growth fault signature in less permeable areas is more subtle; more closely spaced electrical measurements would be required to detect anomalies in these areas.

\section{SUMMARY AND CONCLUSIONS}

This study described the salinity distribution in the Topstratum (a Holocene-age formation consisting of deltaic sediments) and in the Substratum (a Late Pleistocene and Early Holocene fluvial sand) and evaluated its significance relative to hydrodynamics and hydrogeochemistry. Water trapped in a saltwater or freshwater marsh leaves a distinctive electrical signature that is a function of total dissolved solids. 
Low resistivities in Holocene clays indicate the presence of a buried salt marsh; low resistivities in sands of the Substratum indicate the presence of growth faults. Episodic geopressuring along growth faults produces an anomalous electrical signature in near-surface sediments. High resistivities are associated with a former freshwater marsh and with unfaulted aquifers of the Coastal Lowland Aquifer System.

Salinity variations inferred from electrical data do not completely predict either a Ghyben-Herzberg model or the conceptual model described by Martin and Whiteman (1989). The fine-grained clays and muds of the Topstratum are more likely to retain deposition water; while the coarse-grained sands of the Substratum are continuously flushed by groundwater in the regional flow system and by episodic geopressured water generated by active growth faults (Roberts and Nunn 1994).

\section{REFERENCES}

Anderson, R.N., P. Flemings, S. Losh, J. Austin, and R. Woodhams, 1994, Gulf of Mexico Growth Fault Drilled, Seen as Oil, Gas Migration Pathway, Oil \& Gas Journal, A Pennwell Publication, 7 pp.

Bernard, H.A., and R.J. Leblanc, 1965, Resume of Quaternary Geology of the Northwestern Gulf of Mexico Province, in Quaternary of the United States, H.E. Wright and D.E. Frey, eds, Princeton University Press, Princeton, New Jersey, pp. 137-186.

Domenico, P.A., 1972, Concepts and Models in Groundwater Hydrology, McGraw-Hill, Inc., 405 pp.

Fisk, H.N., 1954, Sedimentary Framework of the Modern Mississippi Delta, Journal of Sedimentary Petrology, v. 24, no. 2, pp. 76-99.

Grubb, H.F., 1986, Gulf Coastal Plain Regional Aquifer-System Study, in Regional Aquifer-System Analysis Program of the U.S. Geological Survey, Summary of Projects, 1978-84, R.J. Sun, ed., pp. 152-162.

Hunt, J.H., 1990, "Generation and Migration of Petroleum from Abnormally Pressured Fluid Compartments," American Association of Petroleum, Geologists Bulletin, 74(1):1-12.

Kolb, C.R., and J.R. Van Lopik, 1958, Geology of the Mississippi River Deltaic Plain, technical report 3-483, U.S. Army Corps of Engineers, Waterways Experiment Station.

Kuecher, G.J., N. Chandra, H.H. Roberts, J.N. Suhayda, S.J. Williams, S. Penland, and W.J. Autin, 1993, Consolidation Settlement Potential in South Louisiana, Proceedings of Coastal Zone 1993, 8th Symposium on Coastal and Ocean Management, New Orleans, La.

Kuecher, G.J., 1994, Geologic Framework and Consolidation Settlement Potential of the Lafourche Delta, Topstratum Valley Fill: Implications for Wetland Loss in Terrebonne and Lafourche Parishes, Louisiana, Doctoral Dissertation, Louisiana State University, Baton Rouge, La, 346 pp.

Martin, A. Jr., and C.D. Whiteman, Jr., 1989, Geohydrology and Regional Ground-Water Flow of the Coastal Lowlands Aquifer System in Parts of Louisiana, Mississippi, Alabama, and Florida--A Preliminary Analysis, U.S. Geological Survey, Water-Resources Investigations Report 88-4100, 88 pp.

McGinnis, L.D., M.D. Thompson, S.F. Miller, D.O. Johnson, P.L. Wilkey, V.L. Scott, P.F. Connor, G.J. Kuecher, S. Penland, and H.R. Isaacson, 1992a, Significance of Geophysical and Engineering Properties of the Holocene in an Abandoned Mississippi Delta Plain: 41st Conference of the S.E. Section, Geological Society of America.

McGinnis, L.D., M.D. Thompson, S.F. Miller, D.O. Johnson, P.L. Wilkey, V.L. Scott, G.J. Kuecher, S. Penland, and H.R. Isaacson, 1992b, Hydrogeophysics of the Louisiana Wetlands, American Geophysical Union, EOS, Montreal, p. H52B.

Penland, S., K.E. Ramsey, R.A. McBride, J.T. Mestayer, and K.A. Westphol, 1988, Relative Sea Level Rise and Delta-Plain Development in the Terrebonne Parish Region, Louisiana Geological Survey, Coastal Geology Tech. Rept. No. 4, 121 pp. 
Powell, S.T., 1964, Quality of Water, in Handbook of Applied Hydrology, V.T. Chow, ed., McGraw-Hill Book Co., pp. 19-23.

Roberts, H.H., S. Peniand, A. Bailey, and J.N. Suhayda, 1991, Sedimentology, Geochemistry, and Geotechnical Properties of Two Long Borings Through the Terrebonne Holocene Delta Plain: Effect of Early Diagenesis and Lithology on Subsidence. in Coastal Depositional Systems in the Gulf of Mexico, Quaternary Framework and Environmental Issues, 12th Annual Research Conference, Gulf Coast Section, Society of Economic Paleontologists and Mineralogists Foundation, Program with Extended and Mlustrated Abstracts, Houston, Texas, Dec. 1991, pp. 223-230.

Roberts, S.J., and J.A. Nunn, 1994, Expulsion of Abnormally Pressured Fluids Along Faults. unpublished manuscript, Department of Geology and Geophysics, Louisiana State University, Baton Rouge, La.

Thompson, M.D., et al., 1993, Gas-Rich Sediment and Coastal Wetland Loss in Louisiana, symposium on the application of geophysics to engineering and environmental problems, Environmental and Engineering Geophysical Society, vol. 2, pp. 463-476.

Turcan, A.N., 1966, Calculation of Water Quality from Electrical Logs - Theory and Practice. State of Louisiana, Department of Conservation, Geological Survey and Department of Public Works, in cooperation with the United States Geological Survey, Water Resources Pamphlet No. 19; 23 pp. 